\title{
Establishment of the Coast Range ophiolite microbial observatory (CROMO): drilling objectives and preliminary outcomes
}

\author{
D. Cardace ${ }^{1}$, T. Hoehler ${ }^{2}$, T. McCollom ${ }^{3}$, M. Schrenk ${ }^{4}$, D. Carnevale ${ }^{1}$, M. Kubo ${ }^{2}$, and K. Twing ${ }^{4}$ \\ ${ }^{1}$ University of Rhode Island, Department of Geosciences, 9 East Alumni Avenue, \\ Kingston, RI 02881-2019, USA \\ ${ }^{2}$ Exobiology Branch, NASA Ames Research Center, Mail Stop 239-4, Moffett Field, CA 94035, USA \\ ${ }^{3} \mathrm{CU}$ Center for Astrobiology \& Laboratory for Atmospheric and Space Physics, Campus Box 600, \\ University of Colorado, Boulder, CO 80309-0600, USA \\ ${ }^{4}$ East Carolina University, Department of Biology, Howell Science Complex, Greenville, NC 27858, USA \\ Correspondence to: D. Cardace (cardace@uri.edu)
}

Received: 16 July 2013 - Revised: 28 October 2013 - Accepted: 28 October 2013 - Published: 5 November 2013

Abstract. This project aimed to establish a subsurface microbial observatory in ultramafic rocks, by drilling into an actively serpentinizing peridotite body, characterizing cored rocks, and outfitting the boreholes for a program of long-term observation and experimentation to resolve the serpentinite-hosted subsurface biosphere. We completed drilling in August 2011, drilling two boreholes with core recovery and possibility for down-hole experimentation, and six smaller-diameter monitoring wells arrayed around the two primary holes, in the Coast Range ophiolite (CRO) locality in the UC-Davis McLaughlin Natural Reserve, Lower Lake, CA. Every effort was made during drilling to keep the cores and wells as free of drilling-induced contamination as possible: clean, purified water was used as drilling fluid, fluorescent microbead tracers were suspended in that water for quantification of drilling fluid penetration into the cores, and high resolution next generation sequencing approaches were used to characterize the microbial populations in the drill fluids and core materials. In December 2011, we completed installation of well pumps (slow flow bladder pumps) in the monitoring wells, and have deployed a set of in situ incubation experiments in the two uncased boreholes. Preliminary findings illustrate natural variability in actively serpentinizing strata, and confirm distinct groundwater flow regimes and microbial ecosystems in (a) shallow, surface-impacted soil water horizons and (b) deeper, ultramafic bedrocksourced formation fluids.

\section{Introduction and goals/scientific objectives}

\section{Background}

Serpentinites have been the target of numerous deep-sea drilling expeditions over the years, including expeditions to Hess Deep and along the Mid-Atlantic Ridge (e.g., Mével et al., 1996; Karson et al., 1997; Kelemen et al., 2007). Historically, these expeditions were in large part motivated by exploration of the structural, petrologic, and tectonic evolution of the ocean crust. The discovery of the Lost City hydrothermal field (Kelley et al., 2001, 2005) stimulated increasing interest in the capacity of serpentinites to support biological communities, both at and below the seafloor (Schrenk et al., 2013). Recently, interest in the biological potential of serpentinites has begun to extend into the continental realm, leading to the initiation of efforts to drill into serpentinites on land to investigate biological activities that may be occurring beneath the surface. Here, we report on the establishment of a subsurface microbial observatory within an active serpentinite in the California Coast Range.

Serpentinization is a pervasive process in many geologic terranes, however the geochemical processes, rates, and their relationship to microbiology are very poorly constrained. 
The life-supporting potential of serpentinites has been discussed at length (Shock, 1997; Nealson, 1997; Fisk and Giovannoni, 1999; Sleep et al., 2004; Nealson et al., 2005; Schulte et al., 2006; McCollom, 2007; Schrenk et al., 2013), and experimental work has constrained controls on $\mathrm{H}_{2}$ and $\mathrm{CH}_{4}$ generation (Berndt et al., 1996; McCollom and Seewald, 2001; Allen and Seyfried Jr., 2003; Seyfried Jr. et al., 2007). Field-based studies of both fluid discharge sites (Kelley et al., 2001, 2005; Takai et al., 2004; Schrenk et al., 2004) and serpentinized rocks (Alt and Shanks III, 1998; Alt et al., 2007; Schulte et al., 2006) have drawn some boundaries on modern examples of ongoing serpentinization and available bioenergetic resources. Also relevant are the many studies focused on the production of abiotic organic molecules in serpentinites, and possible supply of prebiotic molecules to planetary systems (cf., Shock and Schulte, 1998; Holm and Andersson, 1998; Martin and Russell, 2007; Proskurowski et al., 2008).

In the presence of water at temperatures and pressures characteristic of earth's surface or near-surface environments, olivine in ultramafic igneous rocks alters to serpentine minerals (e.g., lizardite, chrysotile, and antigorite), hydroxides, and magnetite (Moody, 1976; Früh-Green et al., 2004), increasing alkalinity, as shown in by the general reaction:

$$
(\mathrm{Mg}, \mathrm{Fe})_{2} \mathrm{SiO}_{4}+\mathrm{H}_{2} \mathrm{O} \rightarrow(\mathrm{Mg}, \mathrm{Fe})_{3} \mathrm{Si}_{2} \mathrm{O}_{5}(\mathrm{OH})_{4}
$$

\section{Olivine Serpentine}

$$
+(\mathrm{Mg}, \mathrm{Fe})(\mathrm{OH})_{2}+\mathrm{Fe}_{3} \mathrm{O}_{4}+\mathrm{H}_{2}
$$

$$
\text { Brucite Magnetite. }
$$

The stoichiometry of the reaction as well as the compositions of product phases are dependent on a number of factors including temperature, initial rock and mineral compositions, and fluid : rock ratio (e.g., Klein et al., 2009). The $\mathrm{H}_{2}$ is produced through oxidation of ferrous iron by water to ferric iron [Fe(III)], which typically precipitates as magnetite. The process can be represented by the expression:

$2(\mathrm{FeO})_{\text {rock }}+\mathrm{H}_{2} \mathrm{O} \rightarrow\left(\mathrm{Fe}_{2} \mathrm{O}_{3}\right)_{\text {rock }}+\mathrm{H}_{2}$,

where $(\mathrm{FeO})_{\text {rock }}$ refers to the ferrous component of igneous silicate minerals and $\left(\mathrm{Fe}_{2} \mathrm{O}_{3}\right)_{\text {rock }}$ refers to the ferric component of Fe-bearing mineral alteration products, such as magnetite.

Thus, mineral transformations associated with serpentinization can produce significant quantities of $\mathrm{H}_{2}$, a widely utilized source of energy for micro-organisms, and might thereby fuel an attendant biosphere (Nealson et al., 2005). At the same time, serpentinization at low temperatures $\left(<\sim 250^{\circ} \mathrm{C}\right)$ can drive the $\mathrm{pH}$ of ambient waters to levels sometimes in excess of 12 (more alkaline than household ammonia), which may both tax microbial communities and also sequester the inorganic carbon required for metabolism or biosynthesis. The balance of these factors in creating habitable conditions is only beginning to be understood. Additionally, the reactions presented above are idealized; the stoichiometry and rates of production of $\mathrm{H}_{2}$ and hydroxides (along with the postulated potential for hydrocarbon production) depend significantly on the starting composition of rocks and reactive fluids as well as pressure-temperaturecomposition conditions. We are thus faced with the problem of extrapolating the habitability of serpentinizing systems, across a broad range of conditions, from a few "point observations".

The most comprehensive geobiological characterization of a submarine serpentinizing system thus far published is for the Lost City Hydrothermal Field, $\sim 15 \mathrm{~km}$ off the MidAtlantic Ridge. Here, venting fluids sourced in serpentinizing host rock exhibit extreme enrichment in both alkalinity ( $\mathrm{pH}$ of 9-11), and dissolved $\mathrm{H}_{2}(15 \mathrm{mM})$, along with abundant dissolved methane ( $2 \mathrm{mM}$ ) (Kelley et al., 2005). The site also hosts a microbial food web apparently dependent on the chemical disequilibrium furnished by mixing of serpentinizing fluids with deep sea water (McCollom, 2007; Brazelton et al., 2006; Schrenk et al., 2004; Kelley et al., 2001, 2005).

On land, serpentinizing fluids may be harder to locate, as they may have more moderate chemistries (less extreme $\mathrm{pH}$, with or without observable gas inventory) and are trapped within weathering bodies of rock, representing a lower energy environment that may yet persist over geologic time. Fluid circulation may be slower than in submarine settings, without vigorous hydrothermal circulation driven by hot young oceanic crust. Where these fluids find surface expression, the reaction of serpentine seep fluids with our atmosphere produces notable mineralization: serpentinizing waters escaping The Cedars peridotite body in Sonoma county (Morrill et al., 2013; Suzuki et al., 2013) produce undulating travertine $\left(\mathrm{CaCO}_{3}\right)$ terraces at the outflow points of subsurface springs, and the geologically similar Complexion Spring site (Schulte et al., 2006) has a pool of striking white sediment (fine grained serpentine phases with diverse salts, suggested by early description in Bradley (1915) and aqueous geochemistry in Goff et al., 2001). High pH springs sourced in ultramafic units of the Oman ophiolite are also under close study, with extremely low dissolved inorganic carbon (20 to $\left.380 \mu \mathrm{mol} \mathrm{L}^{-1}\right), \mathrm{pH}$ values up to 11.9 , and oxidation-reduction potential as low as $-611 \mathrm{mV}$, indicating a strongly reducing subsurface environment (Paukert et al., 2012). The few geomicrobiological studies conducted so far have been primarily limited to sites of subaerial fluid discharge. Within the serpentinites themselves, conditions for potential life can be expected to be very different. Additionally, the microbial ecology of sites in contact with earth's surface and atmosphere likely depend on oxygen - in the more reducing subsurface, microbes need strategies to oxidize hydrogen with other electron acceptors, a very different challenge. Recent work at the Tablelands Ophiolite in Newfoundland, Canada, has begun to clearly demonstrate the relationships 
between ultrabasic fluids and volatile gases associated with serpentinization and the microbial communities they support (Brazelton et al., 2012, 2013). Although the serpentinitesourced origin of venting fluids at such sites seems to have been clearly established, relatively little is yet published in regard to any associated biological communities. These results are consistent with finding from a deep ultrabasic wells at Cabeço de Vide in Portugal, studied by Tiago and colleagues, demonstrating a high abundance of gene sequences related to anaerobic, hydrogen metabolizing microbial taxa (Tiago and Veríssimo).

Current understanding of the habitability of subsurface serpentinizing systems has been missing a critical component: the comprehensive investigation of a site where ongoing, low temperature serpentinization can be monitored in situ, and in particular, near the site of serpentinization, where it can be monitored directly in the subsurface. This is of primary importance in assessing the natural range of habitats created by serpentinization. Drilling at the Coast Range ophiolite microbial observatory (CROMO) recovered intact rock and sediment samples directly from the serpentinizing subsurface. The successful establishment of the CROMO at Lower Lake, CA (in the McLaughlin Natural Reserve), administered by the University of California-Davis, has allowed characterization, comprehensively and over time, of the geology, geochemistry, and biology associated with serpentinization in situ in the sub-surface.

The project's overarching goal is to understand how serpentinization affects subsurface habitability. We have taken an important first step toward this longer term goal, by establishing a subsurface observatory in an actively serpentinizing body, and conducting an initial suite of integrated characterization. Specific objectives were to

1. Characterize the mineralogy and geochemistry accompanying active serpentinization, with particular emphasis on constraining the processes that may impact habitability most directly (e.g., provision of geochemical energy sources, alteration of fluid chemistry in ways supportive or detrimental to life).

2. Establish a suite of dedicated boreholes in an actively serpentinizing body, and instrument those boreholes to allow for frequent monitoring of the parameters affecting habitability at specific depths.

3. Characterize any microbial communities that may be present in the cored materials, in the associated groundwater, or that may develop within the borehole during the monitoring period.

4. Evaluate how the geochemical environment may support (or not) photosynthesis-independent subsurface life, placing particular emphasis on energy availability, challenges posed by highly alkaline or otherwise toxic conditions, and availability of carbon and micronutrients.
5. Investigate whether organic compounds are present that are indicative of abiotic synthesis pathways or serve as biomarkers of the biological community.

\section{Geologic and microbiological settings}

\section{General site description}

In northern California, the Coast Ranges stretch north $\sim 600 \mathrm{~km}$ from the Golden Gate Bridge in San Francisco, in an area bounded loosely by the Pacific Ocean to the west, the Coast Range of Oregon and Washington to the north, the Klamath Mountains to the NE, the Great Valley of California to the SE, and the drainage of the Sacramento and San Joaquin rivers to the south (Alexander et al., 2006). Serpentine soils occur throughout this region, with distinctive vegetation and ecology, all dependent on the subaerial weathering of ultramafic bedrock, specifically, olivine and pyroxene minerals in peridotite. Blocks of the CRO, equivalent to Jurassic ocean crust tectonically emplaced on land, are reacting with trapped Cretaceous seawater in this region (Peters, 1993; Shervais et al., 2005) and may be experiencing also some degree of meteoric inputs (Peters, 1993).

Historical and new data for ultramafic-hosted groundwater monitoring wells were made available for expedition planning by the Homestake Mining Co., Inc., which completed regional exploration drilling for conducting gold mining in the vicinity. Homestake records indicate a hydrologic flow system characterized by elevated $\mathrm{pH}$, high dissolved $\mathrm{Cr}$ and high $\mathrm{Ca} / \mathrm{Mg}$ ratios, and higher than expected dissolved $\mathrm{H}_{2}$ and $\mathrm{CH}_{4}$. The Homestake wells were created as environmental monitoring wells, without the purpose of monitoring microbiology or organic geochemistry. A project was planned to drill a set of dedicated scientific groundwater monitoring wells, limiting potential microbial contamination, in order to make CRO formation fluids accessible, at the McLaughlin Natural Reserve (Fig. 1), a University of California at Davis-administered research and educational reserve, in Lower Lake, CA.

\section{Drilling strategy/field operations}

Cascade Drilling successfully completed the required drilling tasks despite the challenging condition of using only purified water as a drilling fluid. Coring was accomplished using a Central Mine Equipment Company (CME) Model 75 auger rig, running rods down with auto-hammer $(140 \mathrm{lbs}, 30$ inch stroke). This was HQ coring; HQ indicates a wireline bit size with an outer diameter of $96 \mathrm{~mm}$ and an inner diameter of $63.5 \mathrm{~mm}$. For the rapid installation of remaining water monitoring wells, 8-inch CME hollow stem augers were used, without core retrieval. In all, 37800 gallons (143 088 L) of water were provided by the Ice Water Company, Lower Lake, CA, for use during drilling; all water had passed 


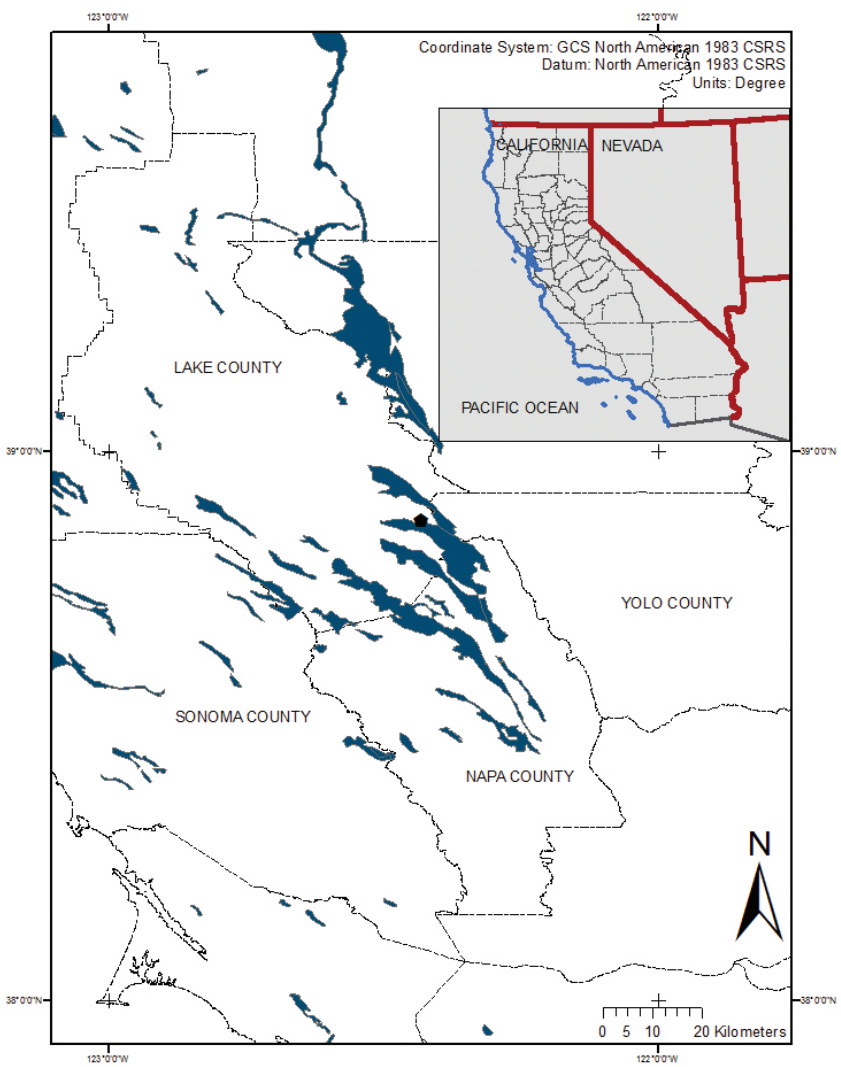

Figure 1. County map of California overlain with serpentinite units colored steel blue in ArcMap10, derived from USGS georeferenced geologic map data (USGS OFR 2005-1305). Drilling took place in Lower Lake, CA in the boundaries of the McLaughlin Natural Reserve, administered by the University of California at Davis, Lower Lake, CA; this site is shown as a black hexagon near the center of map.

through 1 micron filters and ozonated prior to delivery (Supplement Table S1 for certificate of analysis).

No additional muds/lubricants were applied. We added fluorescent $0.5 \mu \mathrm{m}$ polystyrene spheres (Polysciences Inc.) at a concentration of approximately $10^{4}$ beads per $\mathrm{mL}$ of ingoing water to track the movement of microorganism-sized particles through the core material. We utilized best practices developed during biology-themed deep sea drilling investigations, monitoring the penetration of fluorescent microspheres in cores (Smith et al., 2000a, b; House et al., 2003) to track drilling-related contamination of cores. Subsections from both the exterior of the samples and interior to the whole round cores were sequentially washed with sterilized phosphate buffer saline solution, and used to monitor the presence of microspheres. Only those samples free of microsphere contamination were used in subsequent microbiological analyses.

A total of eight wells were emplaced (Table S1 for well monument coordinates). Two primary wells were drilled, from which cores were retrieved, and cased only to bedrock
- leaving the bottom of hole (BOH) uncased. Current depths of wells are as follows. The up-valley primary well is QV1,1 (to $23 \mathrm{~m}$ depth); shallower (QV1,2 was drilled $2.2 \mathrm{~m}$ east of QV1,1 to $14.9 \mathrm{~m}$ depth) and deeper (QV1,3 was drilled $2.1 \mathrm{~m}$ east of QV1,2 to $34.6 \mathrm{~m}$ depth) wells were drilled as close to this priority hole as drilling conditions permitted. The down-valley primary well is CSW1,1 (to $19.5 \mathrm{~m}$ depth); shallower (CSW1,4 was drilled $14.7 \mathrm{~m}$ north of CSW1,1 to $8.8 \mathrm{~m}$ depth), roughly equivalent depth (CSW1,2 was drilled $11.7 \mathrm{~m}$ east of CSW1, 1 to $19.2 \mathrm{~m}$ depth, and CSW1,3 was drilled $11.9 \mathrm{~m}$ west of CSW1,1 to $23.2 \mathrm{~m}$ depth), and deeper (CSW1,5 was drilled $9.4 \mathrm{~m}$ south of CSW1,1 to $27.4 \mathrm{~m}$ depth) wells were drilled in a diamond-shaped array around to CSW1,1. Core recovery observations for the primary wells are as follows. Both primary sites had problems with partial hole collapse upon withdrawal of the drilling tools: driller's depth for QV1,1 was $45.72 \mathrm{~m}$, but current $\mathrm{BOH}$ as determined by logging is $30 \mathrm{~m}$; driller's depth for CSW1,1 was $31.1 \mathrm{~m}$, but current $\mathrm{BOH}$ is $19.5 \mathrm{~m}$ as determined by logging.

Based on the computation of $(100 \times$ total recovered core length)/total cored depth $=\%$ core recovery, $\%$ core recovery for holes QV1,1 and CSW1,1 is taken as $64 \%$ and $46 \%$, respectively. The better core recovery for the QV1,1 site is likely due to the combination of cautious augering followed by coring with the California-Modified Style Split-Spoon Sampler (on a safety driver winch with a $140 \mathrm{lb}$ down-hole hammer with a $30 \mathrm{in}$. stroke), which may be successfully sent through hollow-stem auger borings or direct push tooling, in a generally competent ultramafic block. Though the same drilling strategy was utilized at CSW1,1, the much lower core recovery for this site is likely due to interception of fractured, fine-grained serpentinite in serpentine-dominated clay matrix; much of this material was lost during core retrieval.

Rock cores were curated in a fashion modeled after IODP (Integrated Ocean Drilling Program) best practices. Following photo-documentation and preliminary core description, cores were sampled from combusted aluminum foil sections on the description table and preserved as required for complementary geochemical, microbiological, and organic geochemical analyses within $30 \mathrm{~min}$ of collection. Specified whole round core samples have been archived for geomicrobiology, frozen in liquid nitrogen following collection and maintained at $-80^{\circ} \mathrm{C}$ other than during shipping and freezer transfer to laboratories at East Carolina University-Biological Sciences (Schrenk) and University of Rhode Island-Geosciences (Cardace). Remaining cores are maintained in the University of Rhode Island-Geosciences (Cardace) in conventional storage boxes. Requests to subsample cores will be considered on a case by case basis; existing research management infrastructure at McLaughlin requires research permit application, and the project investigators (Cardace, Hoehler, McCollom, and Schrenk) serve as a committee to facilitate research access to cores and wells. 


\subsection{Mineralogy and geochemistry}

A Terra (distributed by Olympus, formerly InXitu) portable $\mathrm{X}$-ray diffractometer is used for XRD analysis of mineral phases. Standard operating procedures engage a Co X-ray source and a cooled charge-coupled device (CCD) detector arranged in transmission geometry with the sample, with an angular range of 5 to $50^{\circ} 2 \theta$ with $<0.35^{\circ} 2 \theta$ resolution (Blake et al., 2012). X-ray tube voltage is typically $30 \mathrm{kV}$, with a power of $10 \mathrm{~W}$, a step size of $0.05^{\circ}$, and an exposure time of $10 \mathrm{~s}$ per step. Total run time is set at 1000 exposures, requiring about 75 min run time.

XRD samples are powdered using a percussion mortar and agate mortar and pestle; when necessary a Dremel manual drill was used to subsample grains of interest. Powders are passed through a standard $150 \mu \mathrm{m}$ sieve (or 100-mesh). About $15 \mathrm{mg}$ of powdered material is transferred with a spatula to the inlet hopper of the standard sample vibration chamber, which continuously mixes the powdered sample for the duration of the analysis. Interpretation of diffractograms is conducted using XPowder software, which is a commercially available search and match program that queries the PDF2 database for reference mineral peak information.

Once prepared, sample powders are subjected also to bulk XRF analysis by benchtop XRF (Niton XL3T 600) run in atmospheric data collection mode, appropriate for preliminary screening of the geochemistry of bulk soils and sediments according to the EPA 6200 method (US-EPA, 2007); accuracy for analytes $\mathrm{Zr}, \mathrm{Sr}, \mathrm{Rb}, \mathrm{Pb}, \mathrm{As}, \mathrm{Zn}, \mathrm{W}, \mathrm{Cu}, \mathrm{Fe}, \mathrm{Mn}, \mathrm{Cr}$, $\mathrm{V}$, Ti and $\mathrm{S}$ was confirmed by comparison of results for standard reference material TILL-4, a Natural Resources Canada product; for these analytes, a best-fit line for data on a plot of observed vs. reference data proved to have a $R^{2}=0.99966$. Precision was assessed by triplicate analyses of each sample, symbols encompass absolute uncertainty. A more comprehensive analytical data set (via ICP-MS) is in process, but data for $\mathrm{Sr}, \mathrm{Rb}, \mathrm{Fe}, \mathrm{Mn}, \mathrm{Cr}, \mathrm{V}$, and Ti are shared as a Supplement with this report.

Cores comprise pervasively altered peridotite with relic primary minerals olivine/pyroxene, diverse secondary phases including serpentine, magnetite, carbonates, and mixed clays, including chlorite. X-ray diffraction (XRD) data (Fig. 6, Table S2) indicate three main mineral assemblages: (1) a shallow, weathered zone assemblage (Fig. 6, top panel), (2) a serpentine-dominated assemblage (that may also be chlorite-bearing, Fig. 6, middle panel), and (3) an albitebearing assemblage suggestive of mafic rock alteration, likely of a gabbroic body (Fig. 6, bottom panel).

Thin section petrography confirms the broad findings of the XRD results. Figure 7 presents both a representative thin section of a lizardite-rich sample (this variety of serpentine dominates low-temperature serpentinization processes) and

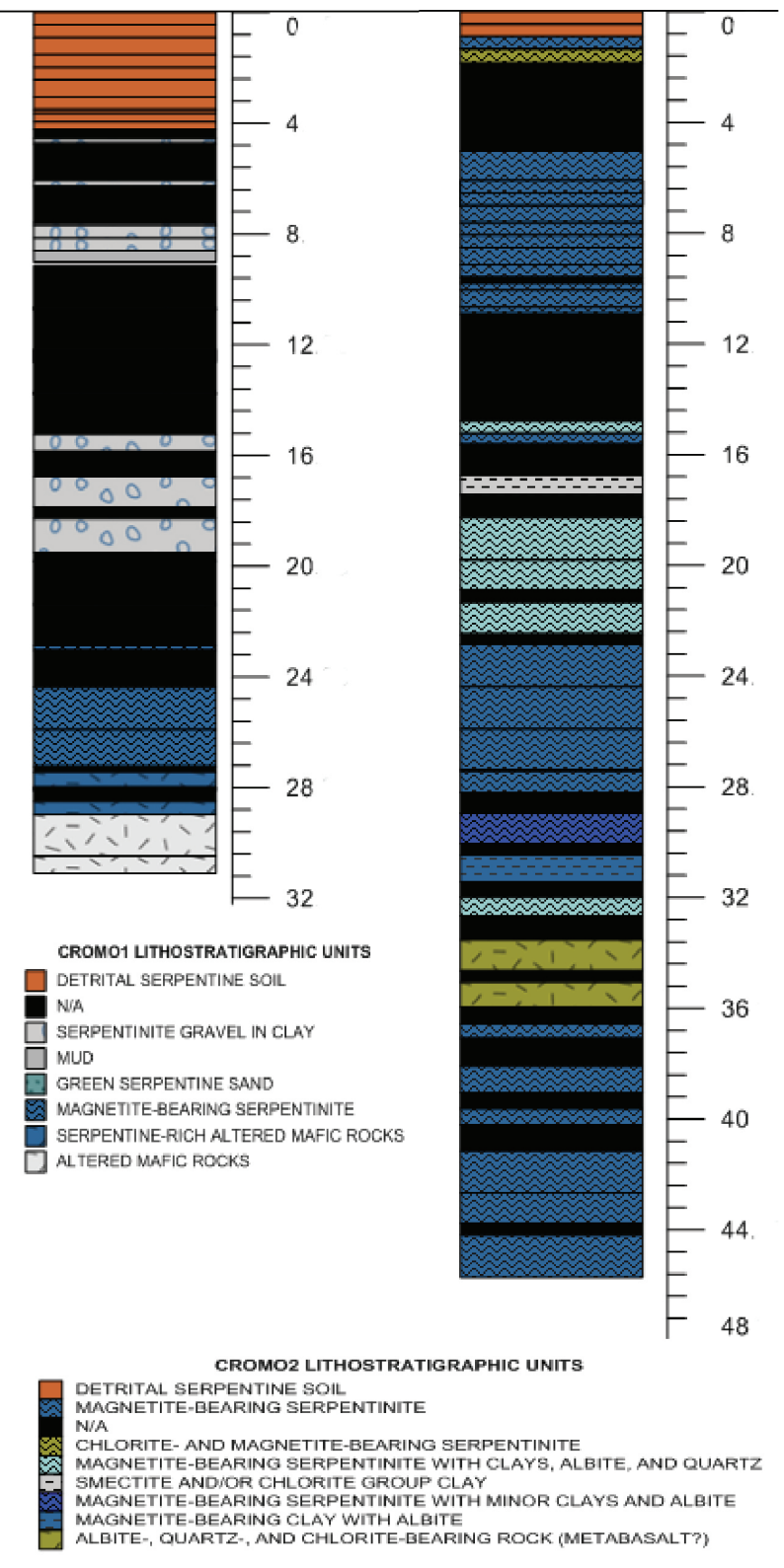

Figure 2. Lithostratigraphic summaries of CROMO1 and CROMO2. Left: CROMO1, the Core Shed area well, was drilled at $38^{\circ} 51.711^{\prime} \mathrm{N}, 122^{\circ} 24.856^{\prime} \mathrm{W}$, and is in a grassy flat with low shrubs and a few introduced trees. Reddish altered peridotite blocks are upslope of the site, with green-blue scrapes showing fresher serpentinite where soil cover has eroded. A few meters of soil was underlain by bedrock. B.O.H. was at a depth of $45 \mathrm{~m}$. Postdrilling measurement of $\mathrm{pH}$ in the uncased borehole gave a $\mathrm{pH}$ of 11.4. Right: CROMO2, the Quarry Valley well, was drilled at $38^{\circ} 51.724^{\prime} \mathrm{N}, 122^{\circ} 25.827^{\prime} \mathrm{W}$, and is characterized by serpentine meadows, steep slopes with altered peridotite outcrops. A few meters of soil graded into less altered material and finally bedrock. Bottom of hole (B.O.H.) was at a depth of $31 \mathrm{~m}$. Post-drilling measurement of $\mathrm{pH}$ in the uncased borehole gave a $\mathrm{pH}$ of 12.5. 


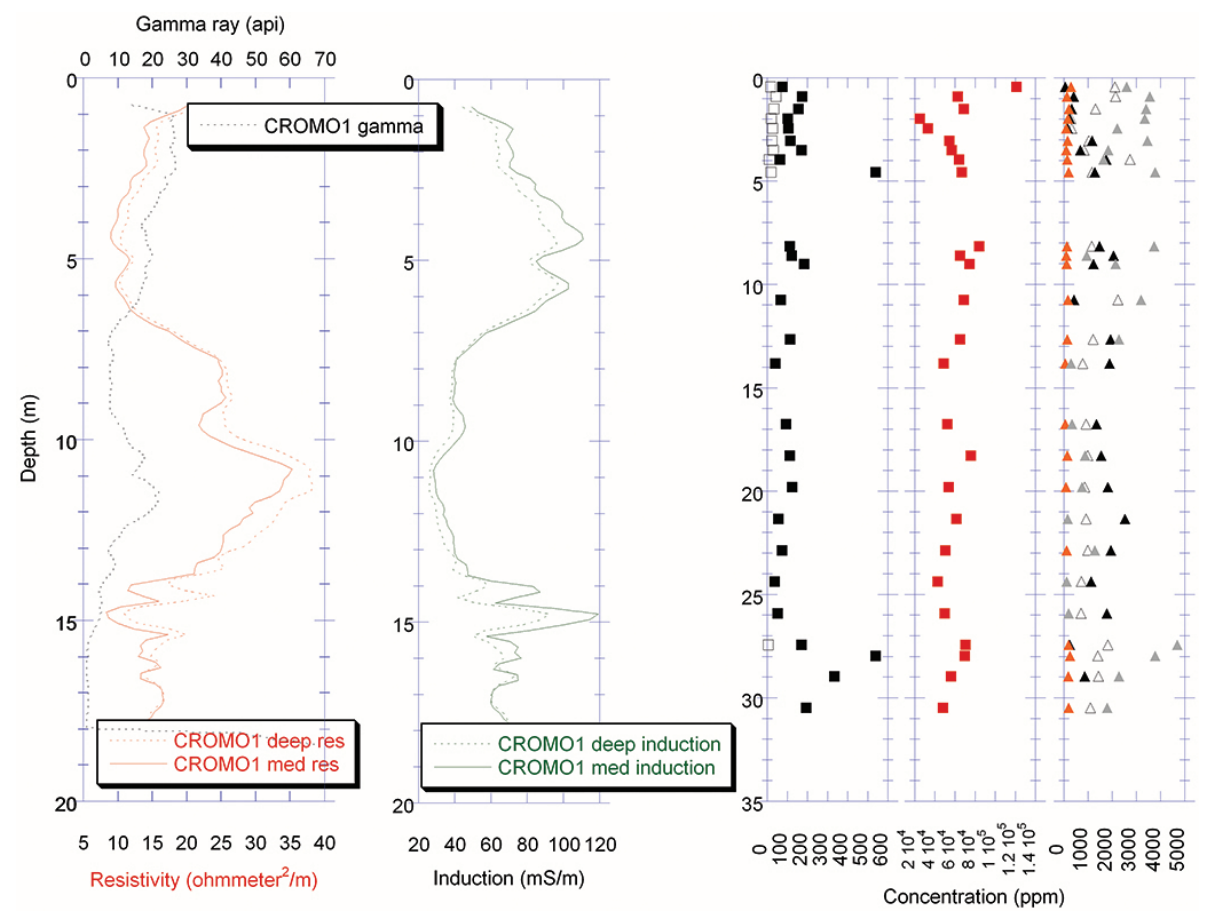

Figure 3. Geophysical logging results (temperature, gamma, induction, resistivity logs) for CROMO1, drilled near the Homestake Mining Inc. Core Shed at the McLaughlin Natural Reserve. In all plots, depth is plotted along the $y$ axis, as meters below surface. Leftmost panel: this depth profile shows variation in gamma ray signal in units of api; $\mathrm{U}$, Th, K-concentrating lithologic units drive values up. Also shown are observed resistivity data in units of $\Omega \mathrm{m}^{2} \mathrm{~m}^{-1}$; medium resistivity conveys information about resistivity near tool, while deep resistivity conveys information about resistivity far from tool in the surrounding formation. Left-middle panel: this depth profile shows observed induction in units of $\mathrm{mSiemens} \mathrm{m}^{-1}$, a measure of induced electrical field in formation rocks; medium induction conveys information about conductivity near tool, while deep induction conveys information about conductivity far from tool. Right trio of panels: bulk powder XRF geochemical data for selected analytes $(\mathrm{Sr}, \mathrm{Rb}, \mathrm{Fe}, \mathrm{Mn}, \mathrm{Cr}, \mathrm{V}, \mathrm{Ti})$ are shown in a trio of plots; $\mathrm{Sr}$ data are filled squares, $\mathrm{Rb}$ data are open squares, Fe data are red squares, Mn data are open triangles, Cr data are black triangles, $\mathrm{V}$ data are brown triangles, and Ti data are gray triangles.

an example of the albitic alteration digesting plagioclase (a characteristic alteration pattern in mafic rocks).

\subsection{Lithostratigraphy}

The first borehole (Fig. 5, left) was drilled in the Quarry Valley area of the McLaughlin Natural Reserve. This area is characterized by a valley bottom comprising riparian vegetation, valley oak (Quercus lobata) woodland, and adjacent meadows supporting a mixture of serpentine-tolerant and serpentine intolerant herbaceous vegetation, flanked by fairly steep slopes with reddish altered peridotite, gabbro, sedimentary rock outcrops or blocks supporting a mosaic of variable chaparral shrub-lands and blue-oak woodland. We encountered a few meters of soil, grading into lesser altered material and finally bedrock. Bottom of hole (B.O.H.) was originally at a depth of $45.72 \mathrm{~m}$; the hole collapsed partially upon removal of rig to $23 \mathrm{~m}$. Post-drilling measurement of groundwater $\mathrm{pH}$ in the uncased borehole gave a $\mathrm{pH}$ of 12.5 .

The second borehole (Fig. 5, right) was drilled in the Core Shed area of the McLaughlin Natural Reserve. This area is characterized by a valley bottom comprising riparian vegetation, valley oak (Quercus lobata) woodland with some introduced trees planted by homesteaders, and adjacent meadows supporting a mosaic of serpentine-tolerant and serpentineintolerant herbaceous vegetation. The location is flanked by slopes with reddish altered peridotite blocks, and green-blue scrapes showing fresher (i.e., less oxidized by surface weathering) serpentinite where the soil cover has eroded, and supporting serpentine chaparral. Here we encountered a few meters of soil, underlain by bedrock. B.O.H. was at a depth of $31.09 \mathrm{~m}$; the deepest part of the hole caved in upon removal of the rig to $19.5 \mathrm{~m}$. Post-drilling measurement of groundwater $\mathrm{pH}$ in the uncased borehole gave a $\mathrm{pH}$ of 11.4.

\subsection{Logging}

Basic geophysical logging following installation of PVC casing was conducted (with Welenco Inc., D. Ihde http: //www.welenco.com) as soon as feasible following drilling, between 11 and 16 August 2011. Temperature data were logged in ${ }^{\circ} \mathrm{C}$, collected with semiconductor temperature 


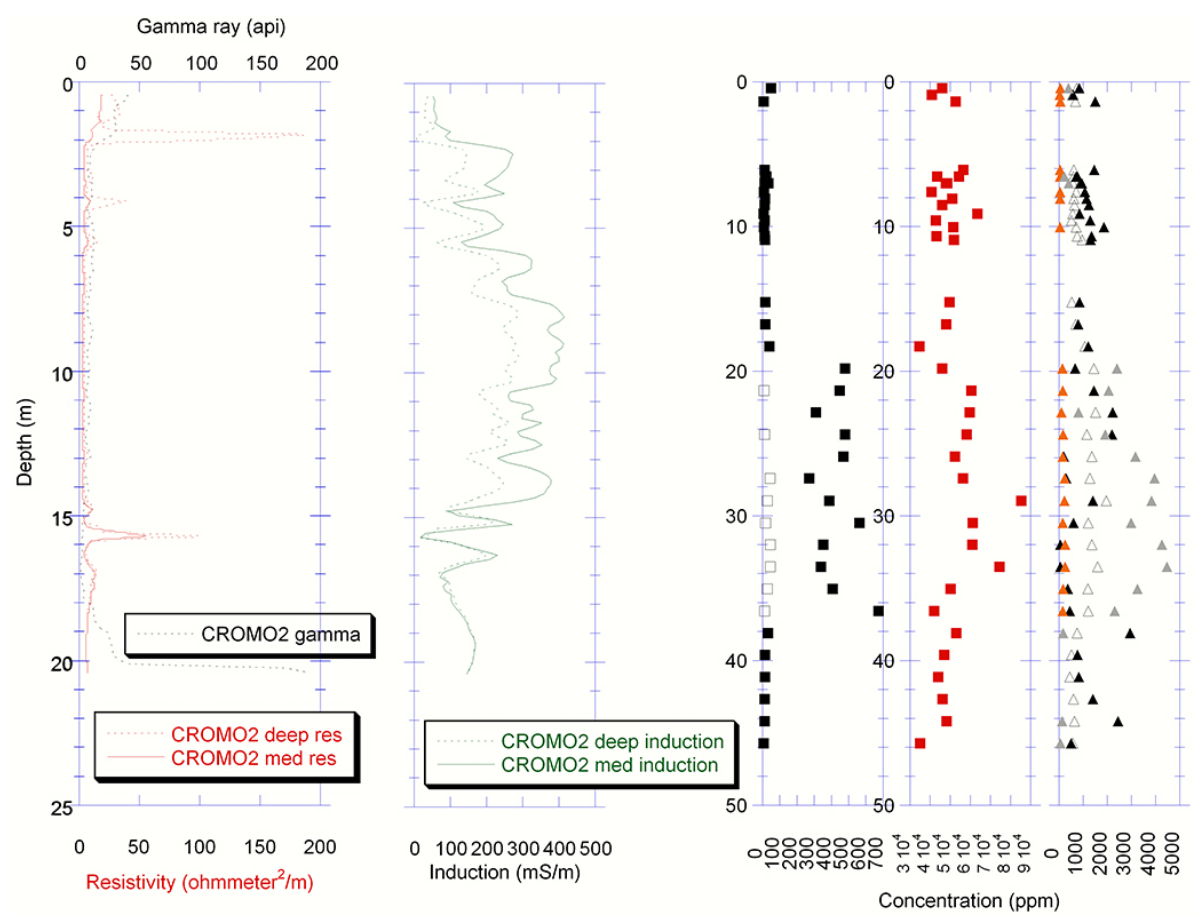

Figure 4. Geophysical logging results (temperature, gamma, induction, resistivity logs) for CROMO2, drilled about $1 \mathrm{~km}$ west of CROMO1, in the Quarry Valley area at the McLaughlin Natural Reserve. In all plots, depth is plotted along the $y$ axis, as meters below surface. Leftmost panel: this depth profile shows variation in gamma ray signal in units of api; U, Th, K-concentrating lithologic units drive values up. Also shown are observed resistivity data in units of $\Omega \mathrm{m}^{2} \mathrm{~m}^{-1}$; medium resistivity conveys information about resistivity near tool, while deep resistivity conveys information about resistivity far from tool in the surrounding formation. Left-middle panel: this depth profile shows observed induction in units of $\mathrm{mSiemens} \mathrm{m}^{-1}$, a measure of induced electrical field in formation rocks; medium induction conveys information about conductivity near tool, while deep induction conveys information about conductivity far from tool. Right trio of panels: bulk powder XRF geochemical data for selected analytes ( $\mathrm{Sr}, \mathrm{Rb}, \mathrm{Fe}, \mathrm{Mn}, \mathrm{Cr}, \mathrm{V}, \mathrm{Ti}$ ) are shown in a trio of plots; Sr data are filled squares, $\mathrm{Rb}$ data open squares, Fe data red squares, Mn data open triangles, Cr data black triangles, V data brown triangles, and Ti data gray triangles. Numerical data presented in Supplement Table S3.

sensor (Robertson Geologging Borehole Logging System temperature/conductivity sonde, model I002055; rated for range of 0 to $70^{\circ} \mathrm{C}$ ); for CROMO1 and CROMO2, logging data stabilize at $14.5^{\circ} \mathrm{C}$ at $13 \mathrm{~m}$ depth and $15.3^{\circ} \mathrm{C}$ at $15 \mathrm{~m}$ depth, respectively. This is a reasonable shallow groundwater temperature for the area. Temperature data do not show any pronounced excursions, which could indicate through-going hydrological flow.

The Dual Focused Induction Sonde (Robertson Geologging Borehole Logging System dual focused induction probe with natural gamma, model I002087; rated for range of 200 to $10000 \mathrm{mS} \mathrm{m}^{-1}$ ) measures natural gamma ray and conductivity of surrounding formations, by monitoring the response of an induced electrical current to local conditions. Figure 3 (for CROMO1, drilled at the Homestake Core Shed area) and Fig. 4 (CROMO2, drilled at western edge of Quarry Valley area) show logging data organized by borehole, with selected geochemical parameters as discussed above. Notice that gamma ray intensity varies from near zero to $\sim 50$ api at CROMO1 (Fig. 3), while it varies from near zero to $\sim 200$ api at $\mathrm{CROMO} 2$ (Fig. 4), suggesting variability in lithologic units across the $\sim 1 \mathrm{~km}$ distance between drilling sites. Induction data (also in Figs. 3 and 4) reflect the conductivity of the tested formation; higher total dissolved solids in a solution results in lower resistivity and higher conductivity, given the inverse mathematical relation of the two terms. As shown, in Fig. 3 at CROMO1, there is a concurrent low induction and high resistivity zone from about 8 to $12 \mathrm{~m}$ below surface, indicating a zone of decreased total dissolved solids. At CROMO2, data shown in Fig. 4, there are several pronounced spikes in deep resistivity (near $2 \mathrm{~m}, 4.3 \mathrm{~m}, 5.5 \mathrm{~m}$, and $15.8 \mathrm{~m}$ depths below surface) in sync with low points in medium and deep formation induction.

\subsection{Microbiology}

The microbiology of the serpentinite subsurface environment is being assessed through analyses of cores obtained during the drilling process and through on-going monitoring of fluids within the resulting wells. To assess microbial abundance within core materials, cells were extracted from formaldehyde-preserved samples, stained with the nucleic 

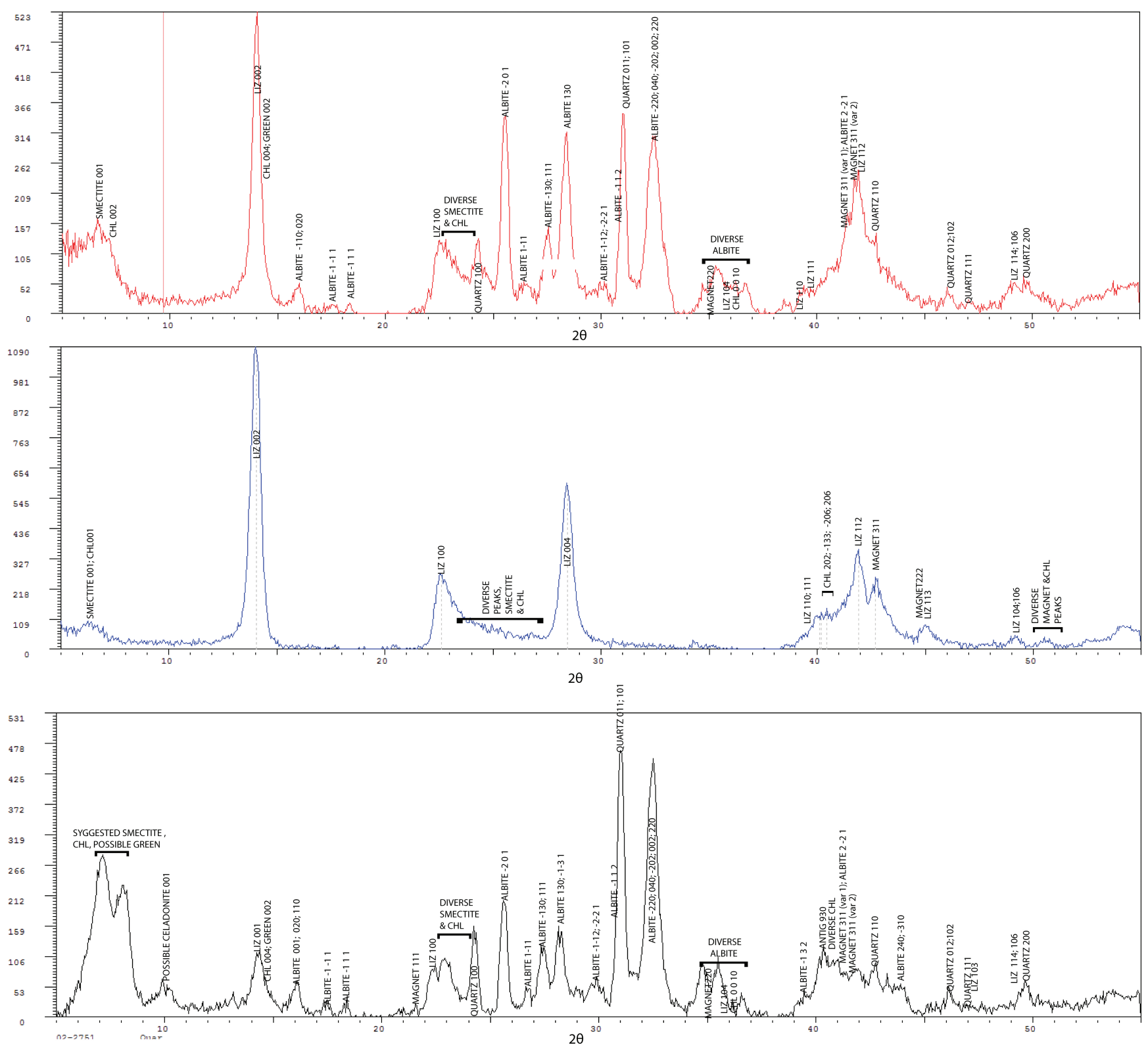

Figure 5. XRD profiles of representative samples from CROMO cores. Identified minerals are labeled, including smectite group clay minerals, chlorite (CHL), lizardite (LIZ), antigorite (ANTIG), greenalite (GREEN), albite, quartz, magnetite (MAGNET), celadonite. Note that lizardite, antigorite, and greenalite are all types of serpentine and not easily distinguished from each other based solely on XRD. Top: a shallow serpentine soil example; CROMO2, 3.5 m below surface. Middle: a magnetite-bearing serpentinite; CROMO2, $25.9 \mathrm{~m}$ below surface. Bottom: an example of a mixed core sample, with serpentine associated with products of basalt alteration in the subsurface; CROMO1, at $33.5 \mathrm{~m}$ below surface.

acid stain DAPI, and quantified microscopically. On average, between $10^{5}$ and $10^{7}$ cells per gram of rock material were evident through microscopic analyses. Fluorescent microbead tracers were quantified in the same preparations. Both culture-dependent and independent methods are being used to determine the microbial community composition of the cored materials. For culture-based approaches, solids from the cores were preserved under nitrogen headspace at
$4{ }^{\circ} \mathrm{C}$ until being used as inoculum for culturing experiments in the laboratory. Enrichment media include incubations containing small organic acids, carbonate, and complex organic matter all under anaerobic or microaerophilic conditions. For culture-independent analyses, nucleic acids were extracted from flash frozen core using a MoBio Power Soil Kit (MoBio Labs, Carlsbad, CA). The resultant DNA was quantified using fluorometric methods, subjected to quantitative PCR of 


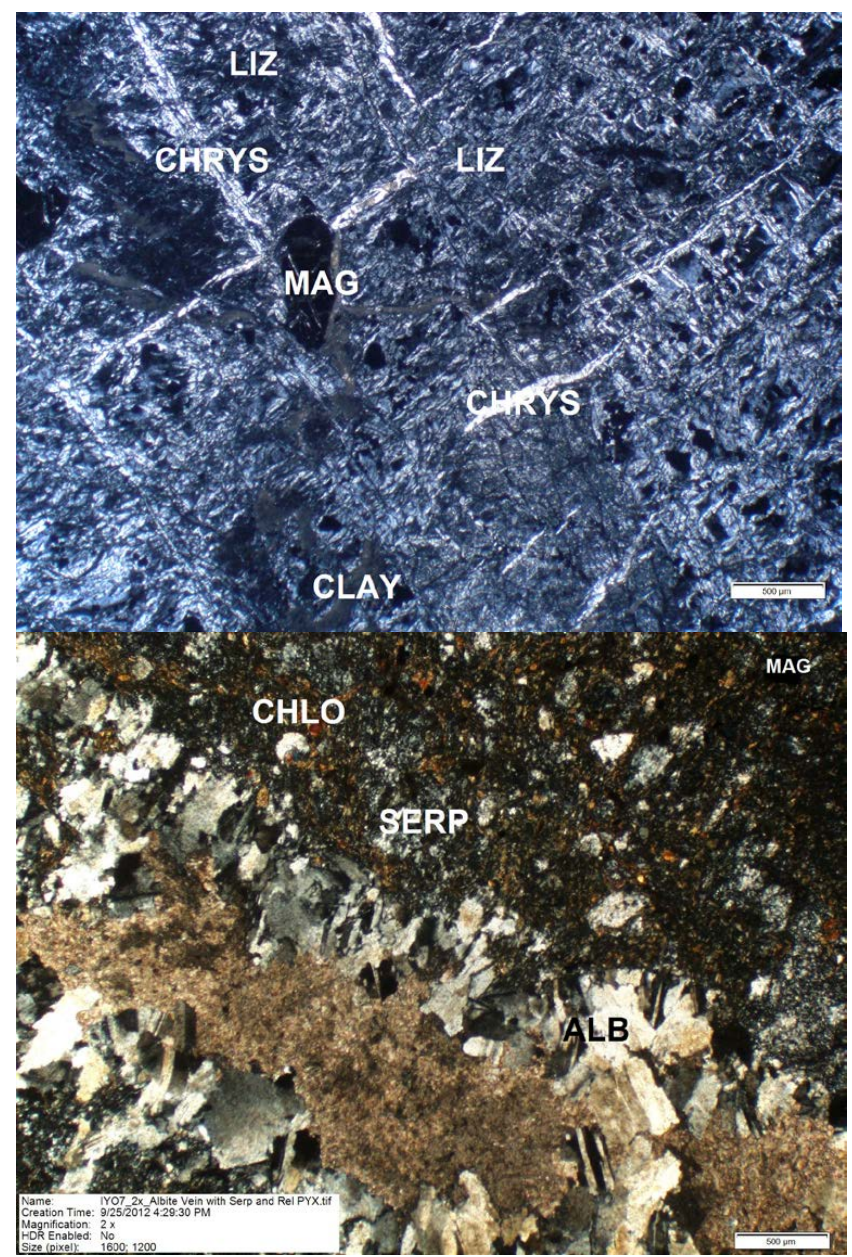

Figure 6. Representative thin sections. Top: CROMO2 at $41.15 \mathrm{~m}$ depth (2X). This thin section confirms the results from the XRD, showing lizardite as the dominant phase, the mesh-like white and blue matrix, with white veinlets of chrysotile and scattered black blebs of magnetite. Some clay minerals are present as well as opaque brown streaks. Bottom: CROMO1 at $31 \mathrm{~m}$ depth (2X). This thin section image was obtained with crossed polarizers applied. Albite crystals are the white and black twinned crystals that appear to extrude diagonally from the SE corner to the NW corner. Serpentine is present as black and white mottled mineral in the $\mathrm{N}$ and NE portion of the slide. Chlorite, another clay mineral shows up as slightly green-hued under cross-polarized light and is pervasive in the thin section.

the 16S rRNA gene of predominant taxa, and used to generate tag sequences. Preliminary results of cores samples suggest an exceptionally low diversity of microbes associated with solid substrates from the serpentinite subsurface environment.

Ongoing sampling of fluids from the wells includes DNA analyses of fluids concentrated via filtration and culturing of microbes using well fluids as inoculum. Initial results show evidence of phylotypes associated with heterotrophy, hydro- gen oxidation, and sulfur and iron reduction in the biomass filtered from serpentinizing fluid samples.

\subsection{Organic geochemistry}

Initial efforts to extract organic compounds from the recovered cores have revealed low amounts of organic compounds. However, both bacterial and archaeal membrane lipids are present. Similarly, solvent extracts of borehole fluids from the adjacent Homestake monitoring wells have been found to contain only a few unusual organic compounds above detection levels, including thiolanes. Overall, initial results indicate that very limited amounts of organic matter may be present in the subsurface serpentinites.

\section{Research implications}

CROMO holds excellent promise as a platform for integrated biogeochemical probing of the serpentinizing subsurface. Core analyses show pervasively altered peridotite, and diverse secondary phases including serpentine, magnetite, carbonates, mixed clays. There is evidence for mafic rock alteration adjacent to ultramafic units, either by juxtaposition of ophiolite-derived mafic units or igneous sill emplacement. To date, findings include

- Bulk core mineralogy for both cored sites is dominated by lizardite (a serpentine polymorph), with magnetite, mixed clays, some albite (metamorphic alteration product), and actinolite/tremolite amphibole phases.

- Bulk core geochemistry shows intervals of elevated/peak iron, chromium, calcium, and titanium, which are likely mineral controlled.

- Field experiments with core materials and well fluids demonstrate biologically mediated uptake of added $\mathrm{H}_{2}$ and $\mathrm{CO}$, with fluids showing higher activity levels than core materials.

- Initial solvent extracts of subsurface rock samples indicate low levels and limited diversity of organic compounds, but include detectable amounts of membrane lipids from both bacteria and archaea.

- Preliminary DNA extractions have been successful and are being used to conduct metagenomics assays on CROMO samples. Microbial communities sampled are mostly dominated by bacteria, with variable occurrence of archaea. High relative abundances of Betaproteobacteria (which in general include hydrogen-oxidizers) have been observed in core samples from Quarry Valley, with closest relatives from other serpentinites in Portugal, the Cedars, and Lost City.

The main implication of these data is that serpentinization is ongoing, with high levels of hydroxide alkalinity and dissolved gases in the formation waters, and this is indeed an 
excellent hub for field investigations of this critical geobiological environment. Because this environment has been so little studied, the data constitute a new baseline for characterizing the habitability of serpentinizing systems. We anticipate rapidly growing interest in these boreholes, from colleagues in astrobiology and deep biosphere research areas, and from those involved in ocean drilling projects in similar earth materials. Management of the CROMO sites will be in accordance with the larger structure of research permitting and rules for the UC-Davis McLaughlin Natural Reserve.

\section{The CROMO Scientific Party}

The CROMO Scientific Party included D. Cardace, T. Hoehler, T. McCollom, M. Schrenk, D. Carnevale, M. Kubo, A. McCann, S. Som, I. Tiago, B. Brazelton, B. Nelson, and S. Chowdhury. K. Twing joined the project postdrilling.

\section{Supplementary material related to this article is available online at http://www.sci-dril.net/16/45/2013/ sd-16-45-2013-supplement.pdf.}

Acknowledgements. We thank the NASA Astrobiology Institute, and the Director's Discretionary Fund under Carl Pilcher, for funding this endeavor. We thank Ed Goolish, Melissa KirvenBrooks, and others at the NAI for continued encouragement and support. The NAI Ames Team remains an invaluable source of advice, as have colleagues across the astrobiology network. This work would not have been possible without the support and aid of the UC-Davis McLaughlin Natural Reserve staff and leadership, particularly Co-Directors Catherine Koehler and Paul Aigner. Members of the Homestake Gold Mining Inc., Co. shared expert time and advice, contributing to the success of this work; the advice and field support of S. Moore is particularly appreciated.

Edited by: U. Harms

Reviewed by: J. Kallmeyer and one anonymous referee

\section{References}

Alexander, E. B., Coleman, R. G., Keeler-Wolfe, T., and Harrison, S. P.: Serpentine Geoecology of Western North America: Geology, Soils, and Vegetation, Oxford University Press, USA, 2006.

Allen, D. E. and Seyfried Jr., W. E.: Compositional controls on vent fluids from ultramatic-hosted hydrothermal systems at midocean ridges: An experimental study at 400 degrees C, 500 bars, Geochim. Cosmochim. Ac., 67, 1531-1542, 2003.

Alt, J. C. and Shanks III, W. C.: Sulfur in serpentinized oceanic peridotites: Serpentinization processes and microbial sulfate reduction, J. Geophys. Res., 103, 9917-9929, 1998.

Alt, J. C., Shanks III, W. C., Bach, W., Paulick, H., Garrido, C. J., and Baudoin, G.: Hydrothermal alteration and microbial sulfate reduction in peridotite and gabbro exposed by detachment faulting at the Mid-Atlantic Ridge, 15 degrees 20' N (ODP Leg 209): A sulfur and oxygen isotope study, Geochem. Geophy. Geosy., 8, Q08002, doi:10.1029/2007GC001617, 2007.

Berndt, M. E., Allen, D. E., and Seyfried Jr., W. E.: Reduction of $\mathrm{CO}_{2}$ during serpentinization of olivine at $300^{\circ} \mathrm{C}$ and 500 bar, Geology, 24, 351-354, doi:10.1130/00917613(1996)024<0351:ROCDSO>2.3.CO;2, 1996.

Blake, D., Vaniman, D., Achilles, C., Anderson, R., Bish, D., Bristow, T., Chen, C., Chipera, S., Crisp, J., Des Marais, D., Downs, R. T., Farmer, J., Feldman, S., Fonda, M., Gailhanou, M., Ma, H., Ming, D. W., Morris, R. V., Sarrazin, P., Stolper, E., Treiman, A., and Yen, A.: Characterization and Calibration of the CheMin Mineralogical Instrument on Mars Science Laboratory, Space Sci. Rev., 170, 341-399, doi:10.1007/s11214-012-9905-1, 2012.

Bradley, W. W.: Mines and mineral resources of the counties of Colusa, Glenn, Lake, Marin, Napa, Solano, Sonoma, Yolo, California State Mining Bureau, Ferry Building, San Francisco, California State Printing Office, No. 14456-A, 1915

Brazelton, W. J., Schrenk, M. O., Kelley, D. S., and Baross, J. A.: Methane- and Sulfur-Metabolizing Microbial Communities Dominate the Lost City Hydrothermal Field Ecosystem, Appl. Environ. Microbiol., 72, 6257-6270, 2006.

Brazelton, W. J., Nelson, B., and Schrenk, M. O.: Metagenomic Evidence for $\mathrm{H}_{2}$ Oxidation and $\mathrm{H}_{2}$ Production by SerpentiniteHosted Subsurface Microbial Communities, Front Microbiol., 2, 268, doi:10.3389/fmicb.2011.00268, 2012.

Brazelton, W. J., Morrill, P. L., Szponar, N., and Schrenk, M. O.: Bacterial Communities Associated with Subsurface Geochemical Processes in Continental Serpentinite Springs, Appl. Environ. Microbiol., 79, 3906-3916, 2013.

Fisk, M. R. and Giovannoni, S. J.: Sources of nutrients and energy for a deep biosphere on Mars, J. Geophys. Res., 104, 1180511815, doi:10.1029/1999JE900010, 1999.

Früh-Green, G. L., Connolly, J. A., Plas, A., Kelley, D. S., and Grobéty, B.: Serpentinization of oceanic peridotites: Implications for geochemical cycles and biological activity, Geophys. Monogr. Ser., 144, 119-136, 2004.

Goff, F., Bergfeld, D., Janik, C. J., Counce, D., and Stimac, J. A.: Geochemical Data on Waters, Gases, Rocks, and Sediments from The Geysers-Clear Lake Region, California (1991-2000), LA13882-MS, Los Alamos National Laboratory, Los Alamos, NM 87545,2001

Holm, N. G. and Andersson, E. M.: Organic molecules on the primitive Earth: Hydrothermal systems, in: The Molecular Origins of Life: Assembling Pieces of the Puzzle, Cambridge University Press, 86-99, 1998.

House, C. H., Cragg, B. A., Teske, A., and the Leg 201 Scientific Party: Drilling Contamination Tests during ODP Leg 201 Using Chemical and Particulate Tracers, in: Proc. ODP, Init. Repts., 201, 1-19 [CD-ROM], edited by: D’Hondt, S. L., Jørgensen, B. B., Miller, D. J., and the Leg 201 Shipboard Scientific Party, available from: Ocean Drilling Program, Texas A\&M University, College Station TX 77845-9547, USA, 2003.

Karson, J. A., Cannat, M., Miller, D. J., and Elthon, D. (Eds.): Proc. ODP, Sci. Results, 153: College Station, TX (Ocean Drilling Program), doi:10.2973/odp.proc.sr.153.1997, 1997. 
Kelemen, P. B., Kikawa, E., and Miller, D. J. (Eds.): Proc. ODP, Sci. Results, 209: College Station, TX (Ocean Drilling Program), doi:10.2973/odp.proc.sr.209.2007, 2007.

Kelley, D. S., Karson, J. A., Blackman, D. K., Früh-Green, G. L., Butterfield, D. A., Lilley, M. D., Olson, E. J., Schrenk, M. O., Roe, K. K., Lebon, G. T., Rivizzigno, P., and the AT3-60 Shipboard Party: An off-axis hydrothermal vent field near the MidAtlantic Ridge at 30 N, Nature, 412, 145-149, 2001.

Kelley, D. S., Karson, J. A., Früh-Green, G. L., Yoerger, D. R., Shank, T. M., Butterfield, D. A., Hayes, J. M., Schrenk, M. O., Olson, E. J., Proskurowski, G., Jakuba, M., Bradley, A., Larson, B., Ludwig, K., Glickson, D., Buckman, K., Bradley, A. S., Brazelton, W. J., Roe, K., Elend, M. J., Delacour, A., Bernasconi, S. M., Lilley, M. D., Baross, J. A., Summons, R. E., and Sylva, S. P.: A Serpentinite-Hosted Ecosystem: The Lost City Hydrothermal Field, Science, 307, 1428-1434, 2005.

Klein, F., Bach, W., Jöns, N., McCollom, T., Moskowitz, B., and Berquó, T.: Iron partitioning and hydrogen generation during serpentinization of abyssal peridotites from $15^{\circ} \mathrm{N}$ on the MidAtlantic Ridge, Geochim. Cosmochim. Acta, 73, 6868-6893, doi:10.1016/j.gca.2009.08.021, 2009.

Martin, W. and Russell, M. J.: On the origin of biochemistry at an alkaline hydrothermal vent, Phil. Trans. R. Soc. Lond. B, 362, 1887-1925, 2007.

McCollom, T. M.: Geochemical constraints on sources of metabolic energy for chemolithoautotrophy in ultramafic-hosted deep-sea hydrothermal systems, Astrobiology, 7, 933-950, 2007.

McCollom, T. M. and Seewald, J. S.: A reassessment of the potential for reduction of dissolved $\mathrm{CO}_{2}$ to hydrocarbons during serpentinization of olivine, Geochim. Cosmochim. Ac., 65, 37693778, 2001.

Mével, C., Gillis, K. M., Allan, J. F., and Meyer, P. S. (Eds.): Proc. ODP, Sci. Results, 147, College Station, TX (Ocean Drilling Program), doi:10.2973/odp.proc.sr.147.1996, 1996.

Moody, J. B.: Serpentinization: a review, Lithos, 9, 125-138, 1976.

Morrill, P. L., Gijs Kuenen, J., Johnson, O. J., Suzuki, S., Rietze, A., Sessions, A. L., Fogel, M. L., and Nealson, K. H.: Geochemistry and geobiology of a present-day serpentinization site in California: The Cedars, Geochim. Cosmochim. Ac., 109, 222-240, 2013.

Nealson, K. H.: The limits of life on Earth and searching for life on Mars, J. Geophys. Res., 102, 23675-23686, doi:10.1029/97JE01996, 1997.

Nealson, K. H., Inagaki, F., and Takai, K.: Hydrogen-driven subsurface lithoautotrophic microbial ecosystems (SLiMEs): do they exist and why should we care?, Trends Microbiol., 13, 405-410, 2005.

Paukert, A. N., Matter, J. M., Kelemen, P. B., Shock, E. L., and Havig, J. R.: Reaction path modeling of enhanced in situ $\mathrm{CO}_{2}$ mineralization for carbon sequestration in the peridotite of the Samail Ophiolite, Sultanate of Oman, Chem. Geol., 330-331, 86-100, 2012.

Peters, E. K.: D- ${ }^{18} \mathrm{O}$ enriched waters of the Coast Range Mountains, northern California: connate and ore-forming fluids, Geochim. Cosmochim. Ac., 57, 1093-1104, 1993.

Proskurowski, G., Lilley, M. D., Seewald, J. S., Früh-Green, G. L., Olson, E. J., Lupton, J. E., Sylva, S. P., and Kelley, D. S.: Abiogenic Hydrocarbon Production at Lost City Hydrothermal Field, Science, 319, 604-607, 2008.
Schrenk, M. O., Kelley, D. S., Bolton, S. A., and Baross, J. A.: Low archaeal diversity linked to subseafloor geochemical processes at the Lost City Hydrothermal Field, Mid-Atlantic Ridge, Environ. Microbiol., 6, 1086-1095, 2004.

Schrenk, M. O., Brazelton, W. J., and Lang, S. Q.: Serpentinization, carbon, and deep life, Rev. Mineral. Geochem., 75, 575606, 2013.

Schulte, M., Blake, D., Hoehler, T., and McCollom, T.: Serpentinization and Its Implications for Life on the Early Earth and Mars, Astrobiology, 6, 364-376, doi:10.1089/ast.2006.6.364, 2006.

Seyfried Jr., W. E., Foustoukos, D. I., and Fu, Q.: Redox evolution and mass transfer during serpentinization: An experimental and theoretical study at $200^{\circ} \mathrm{C}, 500 \mathrm{bar}$ with implications for ultramafic-hosted hydrothermal systems at Mid-Ocean Ridges, Geochim. Cosmochim. Ac., 71, 3872-3886, 2007.

Shervais, J. W., Murchey, B. L., Kimbrough, D. L., Renne, P. R., and Hanan, B.: Radioisotopic and biostratigraphic age relations in the Coast Range Ophiolite, northern California: Implications for the tectonic evolution of the Western Cordillera, Geol. Soc. Am. Bull., 117, 633-653, 2005.

Shock, E. L.: High-temperature life without photosynthesis as a model for Mars, J. Geophys. Res., 102, 23687-23694, doi:10.1029/97JE01087, 1997.

Shock, E. L. and Schulte, M. D.: Organic synthesis during fluid mixing in hydrothermal systems, J. Geophys. Res., 103, 2851328527, doi:10.1029/98JE02142, 1998.

Sleep, N. H., Meibom, A., Fridriksson, Th., Coleman, R. G., and Bird, D. K.: $\mathrm{H}_{2}$-rich fluids from serpentinization: Geochemical and biotic implications, P. Natl. Acad. Sci., 101, 12818-12823, 2004.

Smith, D. C., Spivack, A. J., Fisk, M. R., Haveman, S. A., and Staudigel, H.: Tracer-Based Estimates of Drilling-Induced Microbial Contamination of Deep Sea Crust, Geomicrobiol. J., 17, 207-219, doi:10.1080/01490450050121170, 2000a.

Smith, D. C., Spivack, A. J., Fisk, M. R., Haveman, S. A., Staudigel, H., and ODP Leg 185 Shipboard Scientific Party: Methods for Quantifying Potential Microbial Contamination during Deep Ocean Coring, ODP Tech. Note, 28 [Online], available at: http://www-odp.tamu.edu/publications/tnotes/tn28/ INDEX.HTM, 2000b.

Suzuki, S., Ishii, S., Wu, A., Cheung, A., Tenney, A., Wanger, G., Gijs Kuenen, J., and Nealson, K. H.: Microbial diversity in The Cedars, an ultrabasic, ultrareducing, and low salinity serpentinizing ecosystem, P. Natl. Acad. Sci., 110, 15336-15341, 2013.

Takai, K., Gamo, T., Tsunogai, U., Nakayama, N., Hirayama, H., Nealson, K. H., and Horikoshi, K.: Geochemical and microbiological evidence for a hydrogen-based, hyperthermophilic subsurface lithoautotrophic microbial ecosystem (HyperSLiME) beneath an active deep-sea hydrothermal field, Extremophiles, 8, 269-282, 2004.

US-EPA METHOD 6200: Field Portable X-ray Fluorescence Spectrometry for the Determination of Elemental Concentrations in Soil and Sediment, available at: http://www.epa.gov/osw/hazard/ testmethods/sw846/pdfs/6200.pdf, 2007.

USGS Open-File Report 2005-1305: Preliminary integrated geologic map databases for the United States - western states: California, Nevada, Arizona, Washington, Oregon, Idaho, and Utah, available at: http://pubs.usgs.gov/of/2005/1305/, 2007. 